\title{
BLOOD SERUM BIOCHEMICAL VALUES OF NEONATAL ANTELOPES OF THE SUBFAMILIES REDUNCINAE AND HIPPOTRAGINAE
}

\author{
J. VAHALA ${ }^{1}$ and F. KAŠE ${ }^{2}$ \\ 'ZooVet, Stefánikova 1029, Dvưr Králové nad Labem, 54401 and 2Institute of Biophysics \\ and Nuclear Medicine Charles University, 12000 Prague 2, Salmovského 3
}

Received March 11, 1993

\begin{abstract}
Vahala J., F. Kaše: Blood Serum Biochemical Values of Neonatal Antelopes of the Subfamilies Reduncinae and Hippotraginae. Acta vet. Brno, 63, 1994: 109-113.

Values of 17 blood serum biochemical indicators obtained in 1- to 4-day old antelopes of 10 species of the Subfamilies Reduncinae and Hippotraginae kept in the Zoological Garden at Dvur Králové are reported. Interspecies differences in the values were more pronounced in the Hippotraginae than in the Reduncinae. The values recorded for the neonatal antelopes were compared with the published data on adult animals of the same species kept in the Zoological Garden at Dvur Králové.
\end{abstract}

Antelopes, neonates, captivity, blood serum, biochemistry.

Blood serum biochemical values of captive antelopes have received little attention to date. The present study reports the values obtained in neonatal antelopes of 10 species of the subfamilies Reduncinae and Hippotraginae, namely, mountain reedbucks (Redunca fulvorufula), Lady Grey's waterbucks (Kobus megaceros), lechwe waterbucks (Kobus leche), defassa waterbucks (Kobus ellipsiprymnus defassa), common waterbucks (Kobus ellipsiprymnus ellipsiprymnus), roan antelopes (Hippotragus equinus), sable antelopes (Hippotragus niger), addax (Addax nasomaculatus), scimitar-horned oryx (Oryx dammah), gemsboks (Oryx gazella gazella) in the Zoological Garden at Dvär Králové during the period 1982 to 1990.

\section{Materials and Methods}

Blood samples were withdrawn from the vena jugularis of manually restrained clinically healthy 1- to 4-day old antelopes on the occasion of preventive measures throughout the year. Included in the study were only those neonates that developed no disease during the following 14 days. Basic information on animals of the individual species are presented in Table 1. The blood samples were collected into glass test-tubes and allowed to stand at room temperature. The samples were forwarded to the laboratory for processing within 60 minutes of collection. The blood serum biochemical values were determined with methods used routinely in clinical practice (Pospísil et al. 1987).

Means $(\bar{x})$ and standard deviations (S.D.) were computed from the values obtained for each species regardless of sex. The significance of the differences between the species was analysed using Student's t-test separately for each subfamily.

Table 1

Animals examined - basic data

\begin{tabular}{|c|c|c|c|c|c|c|c|}
\hline & & \multirow{2}{*}{$\frac{\mathrm{n}}{\mathrm{M} / \mathrm{F}}$} & \multicolumn{2}{|c|}{ Collection period } & \multirow{2}{*}{$\begin{array}{l}\text { Age } \\
\text { Days }\end{array}$} & \multicolumn{2}{|r|}{$\begin{array}{c}\text { Body mass of animals } \\
\text { when blood-sampled } \\
\text { kg }\end{array}$} \\
\hline & & & Month & Year & & & \\
\hline $\begin{array}{l}\mathbf{A} \\
\mathbf{B} \\
\mathbf{C} \\
\mathbf{D} \\
\mathbf{E} \\
\mathbf{F} \\
\mathbf{G} \\
\mathbf{H} \\
\mathbf{I} \\
\mathbf{J}\end{array}$ & $\begin{array}{l}\text { Mountain reedbuck } \\
\text { Lady Grey's waterbuck } \\
\text { Lechwe waterbuck } \\
\text { Defassa waterbuck } \\
\text { Common waterbuck } \\
\text { Roan antelope } \\
\text { Sable antelope } \\
\text { Addax } \\
\text { Scimitar-homed oryx } \\
\text { Gemsbok }\end{array}$ & $\begin{array}{l}5 / 6 \\
10 / 11 \\
23 / 23 \\
13 / 7 \\
2 / 4 \\
15 / 22 \\
11 / 8 \\
15 / 9 \\
12 / 6 \\
13 / 18\end{array}$ & $\begin{array}{c}6-8 \\
1-11 \\
1-12 \\
1-12 \\
11-8 \\
3-9 \\
1-7 \\
2-5 \\
3-7 \\
12-5\end{array}$ & $\begin{array}{l}86-90 \\
82-90 \\
86-89 \\
86-89 \\
87-88 \\
85-89 \\
85-89 \\
85-89 \\
85-89 \\
85-89\end{array}$ & $\begin{array}{l}1-4 \\
1-4 \\
1-4 \\
1-4 \\
1-3 \\
1-3 \\
1-3 \\
1-3 \\
1-3 \\
1-4\end{array}$ & $\begin{array}{r}12 \\
20 \\
42 \\
17 \\
6 \\
6 \\
25 \\
11 \\
24 \\
18 \\
31\end{array}$ & $\begin{array}{r}2.5-4.0 \\
5.5-7.5 \\
6.0-10.0 \\
10.0-15.0 \\
11.0-16.0 \\
14.0-23.0 \\
13.0-20.0 \\
6.0-8.0 \\
9.5-11.0 \\
11.5-16.0\end{array}$ \\
\hline
\end{tabular}

$\mathbf{n}=$ No. animals examined

$\mathbf{M}=$ male

$\mathbf{F}=$ female 
Table 2

Biochemical values of neonates of the Reduncinae and Hippotraginae

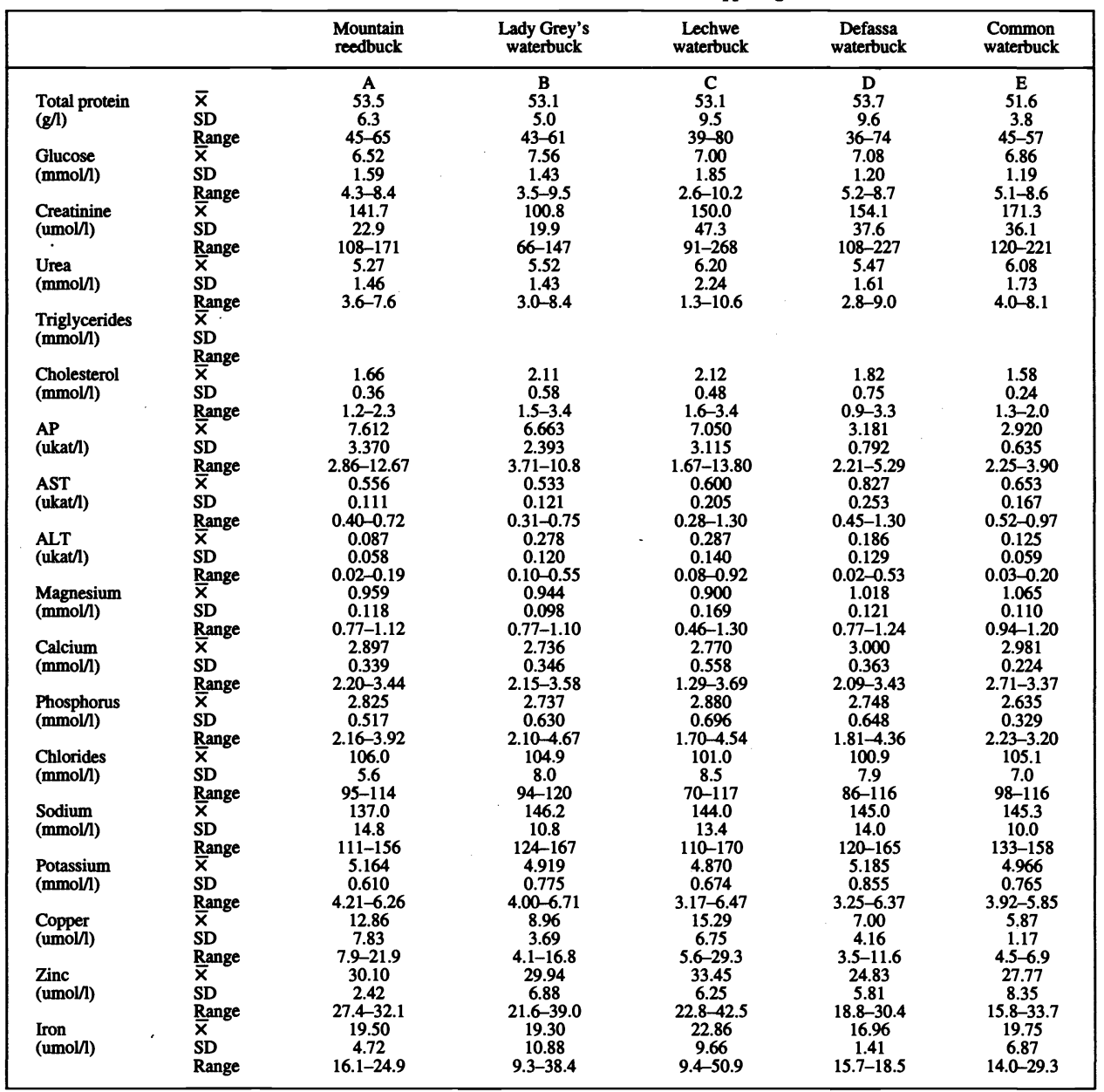

\section{Results and Discussion}

Blood serum biochemical values for the individual species of each subfamily are presented in Table 2.

Statistical differences between the values for the individual species within each subfamily are presented in Table 3.

In the Reduncinae only minimal differences were found between the values for the related species lechwe waterbuck and Lady Grey's waterbuck, creatinine and copper values being lower in Lady Grey's waterbucks. No differences in the values were found between two subspecies, namely, between defassa waterbucks and common waterbucks. Lower ALT values were recorded for mountain reedbucks, lower creatinine values for Lady Grey's waterbucks; higher cholesterol and ALT values were found in Lady Grey's waterbucks and lechwe waterbucks. A higher AST level was found in defassa waterbucks and 
Table 2

\begin{tabular}{|c|c|c|c|c|}
\hline $\begin{array}{c}\text { Roan } \\
\text { antelope }\end{array}$ & $\begin{array}{c}\text { Sable } \\
\text { antelope }\end{array}$ & Addax & $\begin{array}{l}\text { Scimitar-horned } \\
\text { oryx }\end{array}$ & Gemsbok \\
\hline $\begin{array}{c}\text { F } \\
66.0 \\
9.6 \\
51-82 \\
7.21 \\
1.26 \\
4.0-10.4 \\
198.9 \\
39.9 \\
130-295 \\
6.30 \\
2.12 \\
2.5-10.8 \\
1.703 \\
0.692 \\
0.44-2.69 \\
1.69 \\
0.47 \\
0.5-2.7 \\
5.756 \\
2.042 \\
1.30-10.3 \\
0.475 \\
0.141 \\
0.17-0.94 \\
0.109 \\
0.055 \\
0.01-0.22 \\
0.900 \\
0.108 \\
0.55-1.06 \\
2.803 \\
0.413 \\
1.95-3.52 \\
3.038 \\
0.576 \\
1.72-3.96 \\
97.8 \\
8.3 \\
83-117 \\
138.7 \\
11.5 \\
115-160 \\
4.287 \\
0.451 \\
3.08-5.38 \\
12.00 \\
4.82 \\
4.2-22.6 \\
30.28 \\
11.93 \\
17.9-58.2 \\
26.94 \\
12.11 \\
6.3-45.7\end{array}$ & $\begin{array}{c}G \\
63.5 \\
11.6 \\
41-81 \\
7.01 \\
1.00 \\
4.8-9.7 \\
185.8 \\
48.2 \\
127-296 \\
6.23 \\
1.68 \\
3.3-8.7 \\
1.396 \\
0.627 \\
0.46-2.21 \\
1.54 \\
0.51 \\
0.8-2.3 \\
7.346 \\
3.124 \\
2.12-13.5 \\
0.481 \\
0.105 \\
0.31-0.74 \\
0.161 \\
0.080 \\
0.04-0.27 \\
0.971 \\
0.130 \\
0.78-1.30 \\
2.775 \\
0.410 \\
2.28-3.63 \\
2.695 \\
0.327 \\
1.90-3.11 \\
100.6 \\
9.0 \\
84-113 \\
138.5 \\
9.1 \\
124-151 \\
4.704 \\
0.659 \\
3.24-5.75 \\
11.05 \\
3.34 \\
7.5-16.9 \\
29.74 \\
11.21 \\
14.6-54.3 \\
17.31 \\
10.21 \\
4.7-37.8\end{array}$ & $\begin{array}{c}\mathbf{H} \\
50.6 \\
7.7 \\
39-66 \\
8.20 \\
1.45 \\
4.6-10.8 \\
112.3 \\
20.0 \\
89-161 \\
3.83 \\
1.81 \\
1.9-8.9 \\
3.237 \\
0.839 \\
0.20-3.87 \\
1.74 \\
0.53 \\
0.8-2.7 \\
4.738 \\
1.389 \\
2.22-7.37 \\
0.419 \\
0.130 \\
0.21-0.73 \\
0.132 \\
0.074 \\
0.01-0.28 \\
0.917 \\
0.074 \\
0.76-1.04 \\
2.943 \\
0.459 \\
2.18-3.73 \\
2.713 \\
0.487 \\
1.84-3.80 \\
107.4 \\
5.7 \\
94-118 \\
139.4 \\
6.7 \\
127-152 \\
4.751 \\
0.784 \\
3.14-6.01 \\
13.68 \\
4.54 \\
8.0-23.1 \\
27.67 \\
12.18 \\
12.1-51.3 \\
13.56 \\
5.77 \\
9.4-27.0\end{array}$ & $\begin{array}{c}I \\
\text { I } \\
10.5 \\
41-77 \\
8.62 \\
1.23 \\
6.5-10.5 \\
138.0 \\
27.2 \\
102-196 \\
5.41 \\
1.14 \\
3.7-7.8 \\
2.922 \\
0.408 \\
2.43-3.47 \\
2.04 \\
0.59 \\
1.3-3.6 \\
6.780 \\
2.272 \\
3.22-10.7 \\
0.512 \\
0.156 \\
0.19-0.79 \\
0.147 \\
0.082 \\
0.01-0.26 \\
0.900 \\
0.095 \\
0.76-1.03 \\
2.734 \\
0.334 \\
2.17-3.48 \\
2.918 \\
0.407 \\
2.18-3.54 \\
105.0 \\
7.9 \\
86-118 \\
144.2 \\
8.8 \\
130-159 \\
4.643 \\
0.733 \\
3.37-5.90 \\
10.64 \\
2.43 \\
7.1-13.5 \\
39.08 \\
19.68 \\
18.9-66.1 \\
22.88 \\
9.03 \\
13.4-40.7\end{array}$ & $\begin{array}{c}J \\
J 7.6 \\
10.8 \\
40-77 \\
8.25 \\
1.36 \\
5.5-11.1 \\
130.7 \\
20.7 \\
103-184 \\
4.18 \\
1.59 \\
1.8-8.0 \\
2.190 \\
0.762 \\
1.24-3.18 \\
1.42 \\
0.48 \\
0.5-2.4 \\
3.446 \\
1.721 \\
1.40-7.43 \\
0.438 \\
0.143 \\
0.21-0.71 \\
0.102 \\
0.079 \\
0.01-0.28 \\
0.939 \\
0.092 \\
0.74-1.10 \\
2.869 \\
0.386 \\
2.02-3.93 \\
2.513 \\
0.347 \\
1.79-3.19 \\
105.1 \\
6.2 \\
86-113 \\
138.5 \\
11.4 \\
110-155 \\
4.595 \\
0.713 \\
3.11-5.93 \\
10.76 \\
4.29 \\
5.6-18.6 \\
30.19 \\
21.22 \\
8.8-84.6 \\
18.87 \\
8.78 \\
9.0-32.7\end{array}$ \\
\hline
\end{tabular}

lower alkaline phosphatase levels were recorded for defassa waterbucks and common waterbucks.

In the Hippotraginae a degree of similarity in the values depending on the relatedness of the species was also apparent. This applied to roan antelopes and sable antelopes within the group of desert antelopes and to addax, scimitar-horned oryx and gemsboks. However, the interspecies differences in the Hippotraginae were greater than in the Reduncinae. Thus roan antelopes showed higher urea, creatinine, phosphorus and iron levels and lower glucose, triglyceride, chloride and potassium levels. Sable antelopes showed higher urea, creatinine, alkaline phosphatase and ALT levels and lower glucose and triglyceride levels. Addax exhibited lower total protein, urea, creatinie and iron levels, whereas scimitar-horned oryx showed a higher cholesterol level and gemsboks, a lower alkaline phosphatase level.

Up to now, biochemical data regarding neonatal antelopes of the two subfamilies have been scarce. Compared with the values reported for neonatal scimitar-horned oryx by Bush 
Table 3

Statistical significance of differences (in \%) in the values between the species of the Reduncinae and Hippotraginae

\begin{tabular}{|c|c|c|c|c|c|c|c|c|c|c|c|c|c|c|c|c|c|c|c|c|}
\hline & $\begin{array}{l}\text { Redun } \\
\mathbf{A}: \mathbf{B}\end{array}$ & $\begin{array}{c}\text { ncinae } \\
\mathbf{A}: \mathbf{C}\end{array}$ & A:D & $\mathbf{A}: \mathbf{E}$ & B:C & B:D & B:E & C:D & C:E & D:E & $\begin{array}{l}\text { Hip } \\
\text { F:G }\end{array}$ & $\begin{array}{l}\text { ptrag } \\
\text { F:H }\end{array}$ & $\begin{array}{l}\text { lae } \\
\text { F:I }\end{array}$ & F:J & G:H & G:I & G:J & H:I & H:J & I:J \\
\hline Total protein & - & - & - & - & - & - & - & - & - & - & _- & 1 & _ & 5 & 1 & - & - & 1 & 5 & - \\
\hline Glucose & - & - & - & - & - & - & - & - & - & - & - & 1 & 1 & 1 & 1 & $\overline{1}$ & 1 & - & - & - \\
\hline Creatinine & 1 & - & - & - & 1 & 1 & 1 & - & - & - & - & 1 & 1 & 1 & 1 & 1 & 1 & 1 & 1 & - \\
\hline Urea & - & - & - & - & - & - & - & - & - & - & - & i & - & i & i & - & i & i & - & 1 \\
\hline Triglycerides & & & & & & & & & & & - & 1 & 1 & - & 1 & 1 & - & - & - & - \\
\hline Cholesterol & 1 & 1 & - & - & - & - & 1 & - & 1 & - & - & - & 5 & 5 & - & 5 & - & $=$ & 5 & 1 \\
\hline & - & - & 1 & 1 & - & 1 & 1 & 1 & 1 & - & 5 & - & - & 1 & 1 & 1 & 1 & 5 & 5 & 1 \\
\hline AST & - & - & i & - & - & i & - & 5 & - & - & - & - & - & - & - & - & - & 5 & - & - \\
\hline ALT & 1 & 1 & 5 & - & - & 1 & 1 & 1 & 1 & - & 1 & - & - & - & - & - & 1 & - & - & - \\
\hline Magnesium & - & - & - & - & - & - & 5 & 5 & 5 & - & - & - & - & - & - & - & - & - & - & - \\
\hline Calcium & - & - & - & - & - & - & - & - & - & - & - & - & - & - & - & - & - & - & - & - \\
\hline Phosphorus & - & - & - & - & - & - & - & - & - & - & 5 & 5 & - & 1 & - & - & - & - & - & 1 \\
\hline Chlorides & - & - & - & - & - & - & - & - & - & - & - & 1 & 1 & i & 1 & - & - & - & - & - \\
\hline Sodium & - & - & - & - & - & - & - & - & - & - & - & - & - & - & - & - & - & - & - & - \\
\hline Potassium & - & - & - & - & - & - & - & - & - & - & 1 & 1 & 5 & 5 & - & - & - & - & - & - \\
\hline Copper & - & - & - & - & 5 & - & - & - & 5 & - & - & - & - & - & - & - & - & - & - & - \\
\hline Zinc & - & - & - & - & - & - & - & - & - & - & - & - & - & - & - & - & - & - & - & - \\
\hline Iron & - & - & - & - & - & - & - & - & - & - & 5 & 1 & - & 5 & - & - & - & 5 & - & - \\
\hline
\end{tabular}

et al. (1983), the equally old scimitar-horned oryx antelopes in our study showed lower alkaline phosphatase, AST, ALT, and potassium levels and higher glucose, urea and phosphorus levels. These differences may be regarded as due to different husbandry and feeding practices.

Comparison with the values found previously in adult antelopes kept in the Zoological Garden at Dvưr Králové (Váhala et al. 1989a, 1989b, 1991) revealed a similar to equal trend in the development of the biochemical values in all the species under study. Neonatal antelopes exhibited higher alkaline phosphatase, calcium and phosphorus levels and lower total protein, creatinine, ALT and iron levels. Except the addax species they also showed lower glucose levels and, except lechwe waterbucks, lower cholesterol levels. These findings are in keeping with the variations with age in lechwe waterbucks as reported in a previous study (Váhala and Kaše 1993).

\section{Základní biochemické hodnoty krevního séra novorozených mládat antilop podčeledí Reduncinae a Hippotraginae}

V práci uvádíme hodnoty 17 biochemických ukazatelů krevního séra 10 druhủ antilop podceledi Reduncinae a Hippotraginae ve věku 1 až 4 dny, narozených v Zoo Dvůr Králové.

U podčeledi Hippotraginae byly zjištěny výraznějši mezidruhové rozdíly jednotlivých hodnot, než mezi druhy podčeledi Reduncinae. Hodnoty neonatálních jedincủ jsme porovnali s literárními údaji u dospělých zvírat chovaných v zoo Dvůr Králové.

\section{Основныө биохимичөскиө вөличины кровяной сыворотки новорождөнных дөт- өнышөй антилопы подсөмөйств Rөduncinaө и Hippotraginaө}

В работе приведены величины 17 биохимических показателей кровяной сыворотки 10 видов антилоп подсемейств Reduncinae и Hippotraginae в возрасте 1-4 сутки, рожденных в зоопарке Двур-Кралове.

У подсемейства Hippotraginae были выявлены более выразительные межвидовые расхождения отделъных величин по сравнению с видами подсемейства Reduncinae. Величины новорожденных особей сопоставляли с литературными данными взрослых животных, содержаемых в зоопарке Двур-Кралове. 


\section{References}

BUSH, M. - CUSTER, R. S. - WHITLA, J. C. - MONTALI, R. J.: Hematologic and Serum Chemistry Values of Captive Scimitar-Horned Oryx (Oryx tao): Variations with Age and Sex. J.Zoo Anim. Med., 14, 1983: 51-55.

POSPIŚIL, J. - VÁHALA, J. - SPÁLA, P. - KAŠE, F.: Haematological and biochemical values in the peripheral blood of Cape hunting dogs kept in the East-Bohemian zoological garden at Dvưr Králové nad Labem. Acta vet. Brno, 56, 1987: 195-205.

VÁHALA, J. - KAŠE, F.: Serum chemistry profiles for Lechwe waterbucks (Kobus leche): Variations with age and sex. Comp. Biochem. Physiol., 106B, 1993: 47-51.

VÁHALA, J. - POSPIŚIL, J. - POKORNY̛, R. - KAŠE, F.: Blood serum biochemical values of Mountain reedbucks (Reduncula fulvorufula): Variation with sex and season. Acta vet. Brno, 60, 1991: 143-148.

VÁHALA, J. - POSPIŚIL, J. - SPÁLA, P. - KAŚE, F.: Biochemical blood serum values of healthy antelopes kept in the East-Bohemian zoological garden at Dvuir Králové nad Labem - I. The Tragelaphinae, the Hippotraginae and the Aepycerotinae. Acta vet. Brno, 58, 1989a: 17-29.

VÁHALA, J. - POSPIŚSIL, J. - SPÁLA, P. - KAŠE, F.: Biochemical blood serum values of healthy antelopes kept in the East-Bohemian zoological garden at Dvùr Králové nad Labem - II. The Alcelaphinae, the Reduncinae and the Antilopinae. Acta vet. Brno, 58, 1989b: 197-213. 